\title{
Blood, timber, and the state in West Kalimantan, Indonesia
}

\author{
Gerry van Klinken \\ Royal Netherlands Institute of Southeast Asian and Caribbean Studies, KITLV, Reuvensplaats 2, 2311BE Leiden, \\ the Netherlands. \\ Email: klinken@kitlv.nl
}

\begin{abstract}
West Kalimantan (West Borneo) has a history of violent communal conflict. ${ }^{1}$ It also has extensive forests that have been looted for decades. The argument will be that these two are linked, but not by the grievances of the forest dwellers. Except in its first few days, the two main episodes of 1997 and 1999 were not driven mainly by grievances among marginal groups. Rather, explanations based on the 'resource curse' carry more weight. These focus attention on the contested nature of the state, rather than on rebellious activities of marginal groups. When state institutions were thrown into disarray by the sudden resignation of President Suharto in 1998, Dayak militants already close to state power rewrote the rules of local politics by demonstratively 'cleansing' certain areas of an unpopular immigrant minority. This theatrical manoeuvre impressed political rivals sufficiently to allow Dayaks to gain control over several timber-rich districts, which had a thriving black economy. Malays later imitated these techniques to stem the tide.
\end{abstract}

Keywords: communal conflict, grievances, political ecology, resource curse, resource mobilisation, violence

\section{Introduction}

Indonesia experienced many violent local conflicts after the end of the authoritarian New Order in 1998, peaking in 1999-2000. Most in the news overseas were the separatist conflicts in Aceh, East Timor, and to a lesser extent Papua. Six major episodes of communal violence in the same period attracted less attention abroad, yet they claimed about 10000 victims, compared with 9000 for the separatist conflicts (Varshney et al., 2004; van Klinken, 2007: 4-5). ${ }^{2}$ Three took place in Sulawesi and Maluku and were essentially two-sided civil wars, mostly between Christians and Muslims. The other three occurred in Kalimantan and are best seen as one-sided pogroms against an immigrant minority, namely the Madurese. In none was the government or an insurgent a direct protagonist. This paper examines the links with timber resources in two of the three Kalimantan pogroms. Both took place in West Kalimantan. One was perpetrated by ethnic Dayaks in
1996-1997 and another mainly by ethnic Malays in 1999.

Interpreting communal conflict is difficult because the participants often speak a cultural language of identity that obscures material interests. Many observers never get beyond what they first hear the participants saying. The best attempts for West Kalimantan to go a step further come from anthropologists who know the Dayaks well. Several have drawn attention to an environmental aspect. Standing out from the studies of cultural identity that continue to appear on West Kalimantan, this environmental work represents the main interest-based analysis of the West Kalimantan violence.

In order to discern the role natural resources may have played in the communal violence in West Kalimantan, the paper shifts reflexively between events on the ground and various theoretical literatures. It makes two main moves. In the first, the aim is to achieve a better understanding of the possible environmental aspects of violent conflict in West Kalimantan (and by 
analogy other timber-rich parts of Indonesia). This part begins by contrasting two conceptualising literatures on the question. The difference between them hinges on alternative ways of conceiving the dynamics of political conflict, namely a grievance-based and a mobilisational view. It then describes the two violent episodes in West Kalimantan, showing that the second is the most appropriate.

In the second move, the focus shifts to the state. The paper asks how the particular kind of state prevailing in Indonesia becomes vulnerable to mobilisation for violent conflict, in the presence of natural resources such as timber, at a transitional moment such as 1999. Here it concludes that a literature of the 'shadow state' is better than the more common literature of the 'weak state' at capturing what we know about the episodes in West Kalimantan.

\section{Natural resources and conflict}

Anthropologists and political scientists have grown closer in the way they understand the origins of communal (ethnic or religious) conflict. Anthropology took a 'political turn' after the ground-breaking publication of a book edited by Fredrik Barth (1969) which saw ethnic identity as a product of the highly political negotiation across boundaries between neighbouring groups. This led to 'constructionist' rather than 'primordialist' analyses of the origins of communal identity movements. Political science's 'cultural turn', meanwhile, dates to about the same time when it began to acknowledge the constitutive role of culture in social processes (Berger and Luckmann, 1967; Steinmetz, 1999). The same convergence is evident in the way scholars from both disciplines are beginning to view the possible role of natural resources in communal conflict. Both now emphasise the central importance of interested agents. In some ways, the differences within the two communities on the key issues are now greater than the general differences between them.

This paper argues for a particular kind of convergence between political science and anthropology on the question of natural resources and communal conflict. Mainly on the political science side (although the same division exists among anthropologists), it makes the case for an approach that favours mobilisation rather than grievance as the driving force in communal conflict. On the anthropological side, it suggests two things. First, that the most useful level of analysis lies a little higher than the village community (but much lower than national elites). And second, that a more sophisticated model of the state than that now commonly adopted in the Third World political ecology will prove more convincing - not the 'predatory' state but the 'contested' state.

Let us begin with the difference between grievance-based and mobilisational approaches to analysing communal conflict over natural resources. The difference is visible in studies written by people who consider themselves political scientists as well as political ecologists. Those who see conflict as fundamentally driven by grievances commonly employ the term 'relative deprivation', which is a negative emotion (Gurr, 1970). Resource mobilisation literature, on the contrary, prefers to use the term 'opportunity', which exercises a positive allure (Tilly, 1978; McAdam et al., 2001). Elites with establishment connections are an essential element in this school's reading of conflict. Even intolerable grievances, according to these authors, will continue to fester so long as no elites choose to offer leadership.

These two views have also produced two broad approaches to the problem of conflict and natural resources. The 'environmental scarcity' approach traces unrest to grievances among marginal groups over environmental degradation such as deforestation or soil erosion. The 'resource curse' approach considers how the local abundance of a globally scarce resource such as timber or diamonds can weaken the state and embolden rebellious groups to seize opportunities. The labels 'environmental scarcity' and 'resource curse' suggest that one begins with scarcity whereas the other starts with (local) abundance. But the more fundamental divergence is over the motivation of the protagonists in the conflict.

The basic idea of the grievance approach is that unhappiness about environmental degradation can be a significant cause of violent conflict, especially internal conflict. It received heightened attention through the work of the Toronto Group, which emphasised the neoMalthusian significance of population increase 
(Homer-Dixon, 1999). In Indonesia this idea has actually been around for a long time. It became almost a commonplace among anthropologists working on Kalimantan after the early 1980s, when their discipline took a political turn. Until then anthropologists had portrayed Dayaks as tribals isolated from the outside world. Now they began to see them as victims of an environmental squeeze by capitalists and the intrusive state. They warned repeatedly of a Dayak backlash against the loss of their traditional lands. When violence did erupt in 1997, they were quick to conclude it proved them right. ${ }^{3}$

Dayaks themselves affirmed the interpretation. The Dayak activist John Bamba (2000: 40) presented a strong list of such grievances:

For many decades, the government's policies on forest management, religion, education, political activities, and other issues that directly touch the lives of the people created a disempowerment process. For the Dayak in Kalimantan, it caused the destruction of their environment, loss of their land and forest, disempowerment of their local adat [customary] institutions, destruction of their culture, and the creation of uncertainty with regards to their future as indigenous peoples in Kalimantan.

The grievances were real. And yet we never learn exactly how they determined the course of the violence. Grievance-based accounts are methodologically disinclined to take much interest in this question, because they focus on the emotions of the greater number of those who sympathise with the violent action rather than on the organisational activities of the few leaders. Dayak authors who sympathise with the action have even stronger reasons to emphasise grievances but avoid sometimes tawdry organisational details. But when we do begin to look closely, we notice things that do not fit. For example, the grievances do not match the location very well. Sambas district is not the place where deforestation is greatest, nor where plantations have robbed the greatest number of people of their land.

The problem goes deeper. For when we ask how often does environmental degradation become a significant cause of violent conflict around the world, the answer is, apparently, not very often. The Toronto Group has been criticised for failing to come up with convincing evidence that environmental degradation consistently causes violent conflict. A volume edited by Diehl and Gleditsch (2001) clinched the argument. The tone-setting chapter by Goldstone (2001) cites three major statistical studies that all drew negative conclusions. One by Hauge and Ellingsen (2001), in the same book, shows on the basis of comprehensive global data between 1980 and 1992 that deforestation, land degradation and low freshwater availability raise the probability of civil war by less than $1.5 \%$, though they raise the probability of lesser kinds of armed conflict by $4-8 \%$. The risk of violent conflict is in any case high in poor countries that have high income inequality, high population density and low cash income. Environmental degradation is also common in such countries, but its presence only marginally raises the probability of violent conflict. Similar conclusions were reached in the US government-sponsored State Failure Project (Goldstone et al., 2000), and in an earlier extensive study by Baechler (1998), ironically one of the founders of the environmental security approach. Two more recent studies re-examining the neo-Malthusian arguments with fresh data conclude once more that 'doomsayers on the relationship between resource scarcity and violent domestic conflict have very little support' (Theisen, 2006: 20) and '[t]here is little or no support for ecoviolence theories' (de Soysa, 2002: 27). All this makes it more difficult to argue that the Dayak episode in early 1997 was a typical case of protest by marginal groups on environmental grounds.

The 'resource curse' approach was initially discussed in an entirely separate literature. The State Failure Project, for example, did not even allude to it. De Soysa (2002) explicitly contrasted the two literatures, and since then more interaction has emerged. For example, the Worldwatch Institute, traditionally focused on the scarcity perspective, has also begun to pay attention to the resource curse. Both resource curse and environmental scarcity literatures are about the conflict-causing potential of the natural environment. 'Resource curse' is a longstanding concept among economists to explain why economies rich in natural resources often grow poorly. They also call it 'Dutch disease'. Recently, political scientists have begun to think that the same phenomenon could also lead to poor governance (Ross, 1999). Ross' superb 
comparative study of timber regimes in Southeast Asia (2001) demonstrates that rising timber prices caused politicians to throw all sustainability caution to the wind in their rush to seize the available rents. The point of departure in subsequent studies has shifted away from grievances to opportunities, which in turn are intimately linked to the capacities of state institutions. The new direction was signalled in a wide-ranging paper by Fearon and Laitin (2003), arguing that the post-Cold War increase in internal warfare was not related so much to international politics, nor to ethnic or religious diversity per se, as to institutional weaknesses with a history going back to independence in the 1950s and 1960s. Pioneering work with a more strictly rational choice perspective along these lines was done by Paul Collier and his colleagues at the World Bank (Collier et al., 2003; Collier and Hoeffler, 2004). Their interest was in rebel movements that considered 'lootable' natural resources an opportunity to finance their movement. Sierra Leone, Angola and Liberia with their diamonds, oil and timber, were their classic examples. Although also poor, Indonesia is not as dysfunctional as Sierra Leone. Indeed, the Sierra Leone cluster is exceptional because these countries have virtually no formal state (Herbst, 2000). But other studies have broadened the scope to consider political violence in all resource-rich states. Renner (2002) included violent conflicts in Indonesia's Aceh and Papua as examples of civil wars intensified by the presence of abundant natural resources. He shifted the focus away from rebel forces to the states themselves. Somehow a dependence on natural resources weakens state institutions, so they are unable to deal well with dissent. But just how this works remained somewhat unclear.

Natural resources are not all alike in their effects. Oil is the most thoroughly researched (Karl, 1997). A new study disaggregates the possible effects on the risk of civil war of rents obtained from timber, minerals and oil resources (de Soysa and Neumayer, 2003). Using three large global datasets produced by other researchers (two on civil war and one on natural resources), it concluded that the risk of civil war or insurgency goes up dramatically as a country's dependence on oil increases. ${ }^{4}$ Timber and minerals seemed to have no effect on the risk of civil war, but the data were weak in both cases.

One other study that disaggregates natural resources is worth mentioning because of its conceptual innovation, although it does no large-N statistical work. Le Billon (2001) suggests that the field of political ecology (e.g. Bryant and Bailey, 1997) can be turned into a powerful tool to analyse violent conflict and natural resources. The post-Cold War decline in aid has made poor states more dependent on natural resources and this has in turn made them more vulnerable to internal conflict. Volatile, clientelistic and market-based forms of domination grow out of the ruins of the formal state as dependence on resource extraction increases. Le Billon (2001: 567) wrote:

Resource dependent countries thus tend to
have predatory governments serving sectional
interests and to face a greater risk of violent
conflict [...]. The violent conflictuality of
resource exploitation is closely linked to the
failure and degeneration of political systems -
most generally patrimonialism or clientelism -
into 'spoil politics', whereby 'the primary goal
of those competing for political office or power
is self-enrichment' [...]. Many contemporary
wars are inscribed in the legacy of earlier mer-
cantile wars privately financed to serve eco-
nomic objectives and similarly focusing on
resource rich areas and trading posts.

A matrix in Le Billon's paper speculates that different geographies of resources might lead to different kinds of violent conflict, depending on their location (distant or proximate to the centre of governance), and their concentration (point sources like an oil field, or a diffuse resource such as timber). Thus timber, a distant, diffuse resource, leads to warlordism; oil in a proximate place tends to produce coup d'états; oil in a distant place tends to stimulate secessionism; while a proximate diffuse resource (such as agricultural land) leads to riots or rebellions. This is a lot of variables to test with large- $\mathrm{N}$ data, and so far it has not been done thoroughly for timber (but see Rød and Rustad, 2006; Theisen, 2006). Defining the data remains a problem. The global conflict datasets used for these statistical studies so far do not include the Kalimantan communal episodes, usually because they require that the state be a protagonist in the conflict. ${ }^{5}$ We will return to the problem of definition below. 
Let us now turn to what happened in West Kalimantan. Much of it can be described by the dynamics of local elites in crumbling formal polities who exploit opportunities, in the manner highlighted previously.

\section{Elite opportunities and the West Kalimantan violence}

West Kalimantan was known in colonial times as West Borneo. Both major recent episodes of ethnic violence took place in Sambas district, in the large province's northwest corner bordering Malaysian Sarawak. Both involved more or less unprovoked attacks against the local Madurese community. The first left about 500 dead and 20000 internally displaced Madurese. The second may have left somewhat fewer dead - at least 186 but perhaps many more - but it displaced an even greater number - 35000 which swelled to 60000 following another pogrom in 2000. ${ }^{6}$ The Madurese are a small, poor, but popularly despised immigrant community, mostly poor farmers. The government was not a direct protagonist in either of these conflicts, but in both cases it failed to contain the spread of violence. Security forces sometimes shot wildly into trucks carrying attackers. Soon they put more of their resources into evacuating the Madurese for their own safety, thus helping to carry out ethnic cleansing (Davidson, 2002: 374). Several people were jailed for participating in violence, but the organisers were never named.

There were important differences between the episodes. The first in 1997 was carried out by Dayaks, the second in 1999 mainly by Malays. Dayaks and Malays are culturally distinct indigenous groups in West Kalimantan, each making up around a third of the population. The first Dayak episode of violence took place in two waves, 30 December 1996 till 4 January 1997, and then 29 January to the second half of February 1997. In the first wave many small groups, some described as 'hysterical', burned down houses in local Madurese settlements till none were left. The focus was the small town of Sanggau Ledo. The second wave spread to other towns around Sambas district, and beyond it into Pontianak district and Sanggau to the south. It showed a higher level of coordination from the provincial capital Ponti- anak, as well as more clearly enunciated political demands for greater Dayak representation in the bureaucracy.

The second, Malay episode began on 22 February 1999 and ran into April. It followed weeks of intensive planning, and was controlled by a single organisation, Forum Kommunikasi Pemuda Melayu (FKPM, Communication Forum of Malay Youth). This was run by well-connected local businessmen in Singkawang and Pematang, the biggest towns in Sambas district. It drew on a thuggish pool of underemployed young Malay men, of the kind that are readily available at the markets and transport terminals of most towns in Indonesia. The repertoire of the Malay 'rioters' was so similar to that deployed by Dayaks in 1997 that observers spoke of conscious imitation. Each movement seized on popular racism against the Madurese.

The stereotypical Dayak is a tribal who lives in the jungled interior and is pagan or Christian, while the Malay is Muslim and farms near the coast (King, 1993). Dayak ethnic stereotypes of backwardness were shaped by precolonial Malay sultans, paternalistic colonial administrators, missionaries and anthropologists, as well as by the Dayaks' own reactions to them (Peluso, 2003). However, in recent years both Dayaks and Malays have experienced rapid urbanisation and upward social mobility. Urban Dayaks are now challenging Malay dominance in the bureaucracy.

Only the first wave of the 1997 episode looks like the kind of rural grievance-based backlash that anthropologists studying Dayaks had long predicted. It lasted barely a week and was confined to the Sanggau Ledo vicinity. We do not know much about it. The reports hint at frustrations about Dayak land allegedly taken by Madurese. The Madurese are widely regarded as knife-wielding thieves with aggressive manners. In the unsettled atmosphere of a weakening New Order regime, they became lightning rods for popular anxieties, much as politically insignificant gypsies did in Western Europe before Word War II. Key local elites then intensified the moral panic in order to unify a disparate ethnic population in the feeling that 'something must be done'. The second Dayak wave also drew on popular anti-Madurese racism, but this time elite interests were more visible in both the organisation and the framing of the 'conflict'. 
Government-sponsored customary councils (dewan adat), non-governmental organisations and groups attached to the Catholic Church acted as mediators, interpreters and perhaps organisers. Their message was spelled out clearly to a visiting parliamentary delegation from Jakarta: Dayaks want a greater role in local government. For them, the violence was a theatrical demonstration of Dayak power, a means to a political end. The real adversaries in this contest were not the Madurese but the Malays, who dominated the bureaucracy.

Peluso and Harwell's (2001) moving account of the 1997 violence stands as it were on the cusp between the first and the second wave. Methodologically, it rejects the grievance-based environmental scarcity approach of HomerDixon, and embraces the political ecology reasoning that I have here quoted in support of the mobilisational resource curse approach. This is a consistent choice throughout the volume (Peluso and Watts, 2001). Yet it does not make the move towards discerning 'politics by other means', as others have done who adopt the mobilisational approach. Rather it wishes to remain close to the struggles and identities of the ordinary Dayak young people who took part in the ethnic cleansing of Madurese, without ever condoning what they did. Raising the unit of analysis to that of local elites might have created greater explanatory power. The concrete interests of Dayak elites were like those of other local elites in the state-dependent outer islands of Indonesia, namely to control local government. The key actors in these struggles were middle-class urban civil servants and state-dependent building contractors who faced a glass ceiling because of their ethnicity. Dayaks were proportionately under-represented especially in the higher reaches of the district and provincial bureaucracy under the New Order. Their interests led them to take a less oppositional view of government than those less privileged Dayaks who had suffered, as Bamba put it, 'destruction of their environment, loss of their land and forest, [and] disempowerment of their local adat institutions'.

The crucial position in local government in Indonesia is the district head (bupati). All over Indonesia, the decentralisation that followed the end of the New Order devolved greater decision-making and budgetary powers to the district level than before. At the same time, democracy encouraged more open forms of competition for this position. West Kalimantan had seven districts in the New Order (19661998). This increased to 12 through the administrative fragmentation that followed the end of the New Order. The New Order government appointed district heads in a top-down fashion. Many were serving or retired military officers. But in the early 1990s, local movements erupted in several places protesting against New Order centralism. Dayaks were prominent among them. Like similar 'backward' groups around the world (Horowitz, 1985: 167-171), they deployed ethnic mobilisation to demand bureaucratic plums, calling for 'native born' district heads (Malley, 1999). Their activism marked the beginning of the end of the New Order's hegemony. But the new 'ethnic' district heads often retained their military connections. Soon this mixture of ethnic populism and military brokerage became the common pattern of post-Suharto local politics, especially around Kalimantan.

The first Dayak activism for government office took place in 1994. It started in the thickly forested interior, in the remote districts of Sintang, Sanggau and Kapuas Hulu where Dayaks are numerically superior. In Sintang in February 1994, hundreds of Dayaks reacted with violent protest when their favoured candidate for district head was not selected. They blocked the road towards Sintang and smashed car windows. It was the biggest collective action by Dayaks since the early New Order three decades earlier. The following year West Kalimantan's governor brought a peace offering to Dayaks for their loss in Sintang by ensuring a Dayak became district head in Kapuas Hulu. This man was close to the military, and thus unlikely to seriously upset the existing timber regime. Kapuas Hulu is still nearly all forest.

If Dayak assertiveness in the deep interior was a safe move, in the coastal districts of Sambas and Pontianak where they do not constitute a majority it was a risky one. Malays outnumber Dayaks in Sambas more than three to one. It is the most densely populated part of the province after the capital. At that time, it still contained the province's second city, Singkawang, which on many indicators is more prosperous than the provincial capital Pontianak. In Pontianak dis- 
trict, which surrounds the capital, Dayaks are the largest group, but at $33 \%$ they again fall short of an absolute majority. To make their presence felt in these two districts they needed a major demonstration, and that is what they provided by ethnically cleansing the powerless Madurese from Sambas.

The risk paid off. All subsequent negotiations took place against the backdrop of a threatened repeat action by Dayaks (and later by Malays, who imitated the Dayaks). The government's failure to indict the organisers strengthened the Dayak militants. Land grievances that may have motivated the young fighters in early 1997 were now forgotten. Discussions were set in train that resulted by 1999 in the division of Sambas district into two. The eastern part was called Bengkayang, with Dayaks its largest ethnic group. The split was part of a seemingly endless process of administrative involution called pemekaran that began to unfold all over Indonesia after the end of the New Order. In an effort to please everyone, Jakarta carved up districts and provinces into smaller and smaller pieces, each with its own set of new government offices. Another new district named Landak was patched together in 1999 from pieces taken out of northern Pontianak district in such a way as to give Dayaks a majority of more than $80 \%$. In both cases, the Interior Minister took bureaucratic shortcuts to expedite the district subdivision in the belief that it would keep the Dayaks quiet. Both soon had Dayak district heads of their own. When ethnic rioting again broke out in Sambas in 1999, the Dayaks refused to take part. 'We are busy with plans to subdivide Sambas district', a Dayak official told the press, 'If there is a riot, the subdivision of the district might fail'?

Dayak success did not stop there. Sanggau in the interior also had a Dayak district head by November 1998, and so eventually did Sintang. Even in the rump district of Pontianak, where Dayaks made up less than $10 \%$ amid a great diversity of ethnic groups, they managed to have a Dayak elected district head. Militants from the interior intimidated the district assembly in January 1999 by burning cars and then the assembly building itself, until the august body agreed to appoint a Dayak. Thus, by 1999 Dayaks effectively controlled six of the province's nine districts at that time. Most of the new
Dayak district heads were also active ethnic organisers. Some districts such as Bengkayang were viewed as Dayak preserves. Most had a Malay deputy district head as part of a 'powersharing' arrangement. Considering Dayaks had held none of the coveted positions only five years earlier, they had reason to be satisfied. But victory had come at a serious cost to the principle of non-ethnic citizenship. The new rules disenfranchised the one-third of West Kalimantan's population who happened not to have a Dayak or Malay father.

The Malay movement in 1999 was essentially reactive. Davidson (2002: 320) wrote this about it:

Threatened by Dayak mobilization, Malay leaders feared that they would be bypassed as groups jockeyed for positions to best receive the boons of regional autonomy. Recall the 1998 appointments of Dayak bupati in Sanggau and Pontianak districts to understand Malay elite anxiety. So, for the Malay elite, their own 'Malay' resurgence would answer Dayak advances.

The Malay repertoire of ethnic cleansing was imitative, being once again directed at the Madurese. But it was handicapped because Malay leaders could not draw on a highly salient Malay identity as Dayaks could. The challenge for Malay elites was to face down an outright Dayak takeover of Sambas district. However, bolstered by their own somewhat unimaginative show of strength (again picking on Madurese farmers), Malays managed to obtain control over the rump district still named Sambas.

This was clearly no rebellion, but competition within the state. It was so intense in West Kalimatan because the province lacks industry. Urban job-seekers depend greatly on the state, as they do in most areas beyond Java. Urbanisation has been more rapid in West Kalimantan than any other province. Where in 1971 only $13 \%$ of the working population worked outside agriculture, by 1998 that had tripled to $38 \%$. Most who left agriculture moved to town. Simultaneously, government grew significantly. Between the beginning and the end of the 1980s alone, the number of bureaucrats per 1000 head of population more than doubled in West Kalimantan, from 10 to 21 . Nearly $20 \%$ 
of the non-agricultural working population in West Kalimantan were bureaucrats, well above the national average. Dayaks shared in this rush to the city. They also joined the bureaucracy, but the higher reaches remained largely closed to them. For example, the proportion of Dayaks occupying subdistrict head's offices (camat) in West Kalimantan had grown only slowly from $20 \%$ in the 1960 s to $23 \%$ in the 1980 s (Alqadrie, 1990: 293). This fed a sense of Dayak frustration. An expanding urban labour force looking for employment in the civil service is known to be conflictual elsewhere (Goldstone, 2001).

Thus, the two episodes of communal violence in West Kalimantan are best explained through the optic of urban elite interests, rather than those of oppressed, landless Dayaks. No matter how deep the latter's misery was - the anthropologists who lived with them were acutely aware of its depth - their struggle was hijacked by others who shared their ethnicity but not their misery. City folk transformed the struggle into one that served their interests. They chose this moment because state institutions were in disarray as Suharto weakened and then fell, and the incentives for irregular action were great. To understand why, we need to turn to the nature of the state, as suggested in Fearon and Laitin's (2003) epochal paper. This is where natural resources come in.

\section{Weak states and shadow states}

After years of being considered a strong developmentalist state, Indonesia's inability to control the economy and contain communal violence in the aftermath of President Suharto's shock resignation in 1998 exposed the extent to which it has always been poorly institutionalised, riven by factionalism and driven by black money (e.g. Manning and van Diermen, 2000). Parallels with Africa's 'shadow states' suggested themselves, in which political authority is no longer confined to the formal institutions of the state but exercised through the rulers' hegemony of informal markets such as the illicit diamond trade (Reno, 1995). The black economy is also central to Barbara Harriss-White's observations on actual state practices in India. This is that economy where the powerful practise 'fraud and theft from the state, the corrupt abuse of public office, the illegal privatisation of public property rights, the theft or privatisation of public time (moonlighting)' (Harriss-White, 2003: 6). She then defines the shadow state as 'that part of the informal, "real" economy that cannot operate without the particular form taken by the state. . . Hence the real state, including its shadow, is bigger than the formal state, and has a vested interest in the perpetuation of a stricken and porous formal state' (Harriss-White, 2003: 89). In Indonesia, a large proportion of the resource extraction industry falls into the black economy (International Crisis Group, 2001b). Michael Ross (2001) has shown how policy failures resulted from 'rent-seizing' practices stimulated by rising timber prices in Malaysia, the Philippines and Indonesia the last several decades (see also Dauvergne, 1997; Ascher, 1998). In Indonesia, the state must be disaggregated to be understood. In West Kalimantan's timber-rich districts, that shadow state is the arena where district heads (and military officers, district attorneys, etc.) become rich and finance their office expenses by protecting illegal timber felling, by collecting reforestation taxes without passing them on to Jakarta, and a host of similar activities.

What is not evident from these earlier studies on state weakness, however, is how these practices can become conflictual at times of political transition. The key lies in regulation and enforcement, which are just as important in the shadow state as in the formal state. Local power-holders sometimes use armed police and soldiers, in either their private or official capacity, for those ends. However, more than in the formal state, regulation in the shadow state also requires an ethic of trust and reputation. This is how ethnicity, or 'culture' more broadly, enters the shadow state. Violence occurs not because rebels oppose the state from without but because the state itself is contested from within. State actors sponsor ephemeral ethnic organisations that in turn mobilise constituents for (possibly violent) demonstrations of prowess. Le Billon's term 'warlordism' comes closer to this than the term 'civil war' often used in the global conflict datasets.

Most West Kalimantan district heads derive income from the timber industry in their district. All the communal violence after the end of the New Order occurred in the timber-rich outer islands beyond Java. Besides West Kalimantan, 
violence was also linked to the presence of timber in Central Kalimantan (Casson, 2001b; van Klinken, 2002), and Central Sulawesi (Harley, 2003). Timber is also an important industry in the similarly conflictual provinces of Maluku and Irian Jaya. (On the other hand, East Kalimantan, not particularly conflictual, is about as timber-dependent as Central Sulawesi). On the whole, this strengthens the suspicion that timber, a fairly easily lootable resource, has been a curse that weakened the state in timberrich places and made it less able to cope with social tensions.

We do not have a systematic overview of the political economy of illegal timber in West Kalimantan, but scattered news reports give hints. Without judging their rights and wrongs, we sense that timber provides lucrative and potentially transgressive rent-seeking opportunities to the district heads as well as their business partners (the military, police, Malaysian timber bosses, and so on).

- District heads were for a time in the year 2000 permitted to issue 100-hectare forest concessions to local interests $(\mathrm{HPHH}, \mathrm{Hak}$ Pemungutan Hasil Hutan). Some observers described this system as 'an abuse of power' that merely allowed district heads to demand bribes from local businessmen, since the local groups usually teamed up with bigger players to exploit the forest. Kapuas Hulu and Sintang district heads were cited as prolific concession givers. ${ }^{8}$

- They collected a timber tax for the Reforestation Fund (Dana Reboisasi) from these small concessions, but the district heads in Kapuas Hulu, Sintang, Sanggau, Ketapang and Pontianak districts did not pass these substantial sums up to Jakarta. Environmentalists labelled the case 'environmental criminality in the regions' ${ }^{9}$

- District heads acquired a reputation of resisting central government attempts to control rampant illegal logging. Sanggau's district head was mentioned, ${ }^{10}$ and the heads of Kapuas Hulu and Pontianak district were prosecuted for illegal logging. ${ }^{11}$ The new districts of Melawi and Sekadau were also rife with illegal logging, all done by Malaysian businessmen. ${ }^{12}$ Explaining his inability to control it, the Kapuas Hulu district head said the people in his district were like a hungry tiger offered a huge chunk of meat but not allowed to eat it. 'So it is with the forest, they wouldn't cut it down if they had another source of income'.$^{13}$

- Even when reports do not explicitly mention a district head, it is difficult to imagine how they could remain untouched by the profitable illegal logging in their district. In any case, they are never reported taking effective action against it (hardly surprising because that would mean challenging the military who protect the loggers). National parks and remote border areas were particularly vulnerable. ${ }^{14}$

Central Kalimantan has been more intensively studied in this regard, and the parallels are instructive. Anne Casson (2001a: xiii) writes as follows about the district head's dependency on illegal logging revenues in Kotawaringin Timur, in the western part of Central Kalimantan bordering West Kalimantan:

In the era of regional autonomy, the Kotawaringin Timur government is increasingly relying on the district's forest resources for income. In doing so, it has effectively legalised and legitimised illegal logging in the district and wrested much of the revenues obtained from largescale logging from the provincial and central governments. For example, the district government was able to generate an estimated US\$ 6.2 million from the natural resource sector in 2000. More than half of this revenue was obtained from the illegal logging trade alone.

John McCarthy (2006, 2007) has demonstrated with great insight how similar rentseeking mechanisms operated elsewhere in Central Kalimantan and in Sumatra. District heads appear in these analyses as the essential brokers between both legal and illegal businesses and the local resource environment. The district head has always played such a role, but increased local autonomy after the end of the New Order heightened the formal powers attached to the office, at least for several years until Jakarta began to wind them back. In essence, local autonomy meant a greater spread of rent-seeking powers among a host of local state actors, from the district head to the assembly chairperson, from the police chief to the local military commander, and from the various heads of government agencies to the state 
prosecutor. In general, the movement was away from central agencies and the military, towards a proliferation of local agencies and the police.

In West Kalimantan that localizing movement for control of the timber industry had a distinctly cultural or ethnic cast. After the astonishing Dayak victories of early 1997, local councils of elders began confronting timber companies with 'customary fines' (Davidson, 2002: 272). The new ethnic district heads spoke the same language of customary authority. They were converting their cultural capital into hard cash.

The parallels between West and Central Kalimantan are not perfect. West Kalimantan no longer depends as much on timber. ${ }^{15}$ Decades of unsustainable logging have depleted the once near-total forest cover and left timber resources unevenly distributed around the province. Only the eastern-most district of Kapuas Hulu retains almost full forest cover. However, all other districts have some forest. ${ }^{16}$

One indication of a vigorous shadow state is the corruption scandals that hover over it. In West Kalimantan, many do revolve around timber, as we have already seen above, but not all. The classic scandal at the district level is nepotism in the application process for new bureaucrats, which indicates how desirable such positions are in the urban economy. This issue, perennial everywhere in Indonesia, also reached the papers in Sanggau, Sintang, Sambas and Pontianak in late 2002. Other corruption scandals involved the diversion of government educational money into a political slush fund (Pontianak), a failed transmigration project (Sanggau), corrupted tax receipts from bird nests (Kapuas Hulu) and corrupted refugee assistance money (Sambas).

Forest resources in West Kalimantan did not fuel a rebel movement, but weakened the state such that internal factionalism along ethnic lines led to violent conflict at a moment of political transition, namely the end of the New Order. Thus, we need not only to distinguish among various kinds of natural resources, as was done by de Soysa and Neumayer (2003) and Le Billon (2001), but we must also distinguish between different kinds of states. In some countries, like Sierra Leone, the formal state has failed so thoroughly that virtually all authority is rooted in the shadow state. In such countries, warlordism may well be the best description of what happens in timber-rich areas, as Le Billon predicts. In others, such as India or Indonesia, the formal state retains enough coherence to prevent the emergence of local warlords who take no orders from the capital. Here various regime factions back violent ethnic movements to overwhelm their rivals for control of the local state, while using timber resources to buy military and police protection and immunity from the law.

\section{Conclusions}

Seen close up and in the short term, the communal violence in West Kalimantan of early 1997 may appear to confirm the view that it was driven by grievances over environmental degradation. This is especially true of its earliest phase. However, as violent collective action became better organised, it was increasingly transformed into a repertoire deployed by local ethnic elites in their struggle to seize opportunities presented by a weakening central authority. Their interests differed from those of the victims of deforestation. Timber - a relatively 'lootable' natural resource directly controlled by local authorities - played a significant role in the black economy of these frontier areas. By 1999 the memory of the violence had itself become an effective part of the repertoire, deployed for the ethnic redistribution of district level power after the collapse of the New Order. So effective was it that Malays soon began to imitate it in an attempt to introduce a balance of force by the new set of rules.

This conclusion was reached by adopting a mobilisational view of how conflict develops. This view is now common among political scientists, but is also growing among those political ecologists who place their level of analysis a little higher than the village. It focuses on the role of local elites, for whom sudden surges in ethnic identity are a resource available for 'politics by other means'. When combined with a view of the contested Third World state in which rent-seeking links the formal state with informal markets, and in which ethnic trust plays a large role in (possibly violent) regulatory mechanisms, we obtain a fairly coherent understanding of the relationship between ethnic conflict and natural resources. 'Lootable', locally controlled natural resources such as timber play a 
crucial role as sources of rents for those same local elites, who draw their considerable power not merely from their formal function but also from their share of control over the market in timber. In short, ethnic identities are mobilised, and resource conflicts contribute to ethnic mobilisation, when local elites vie for domination under conditions of a crumbling formal state. This points primarily to the long-term need to build effective, democratic state institutions.

\section{Notes}

1 Huge thanks to Jefferson Fox, Arun Swamy, Nancy Peluso and Nils Petter Gleditsch for helpful feedback.

2 There were also many riots, lasting a couple of days and confined to particular cities, widespread 'social violence' such as lynching alleged thieves and witchdoctors, as well as terrorist violence. The number of fatal victims in each category fell far below those from communal violence.

3 For example, Dove (1982); International Crisis Group (2001a); Linder (1997); Lowenhaupt Tsing (1993); Padoch and Peluso (1996); Peluso and Watts (2001). An inaccurate but widely quoted account of this episode as part of a global survey also calls the Kalimantan conflict a 'resource war' driven by Dayak grievances (Klare, 2001: 202-208).

4 Surprisingly, the risk peaks when dependency reaches around $15-25 \%$ of GDP, and declines after that. Possibly the reason is that totally oil-dependent countries are rich enough to afford an effective police force.

5 See http://www.pcr.uu.se/database/ and http://new. prio.no/CSCW-Datasets/Data-on-Armed-Conflict/ UppsalaPRIO-Armed-Conflicts-Dataset/.

6 Human Rights Watch (1997); Background information on the IDP situation in Indonesia, Norwegian Refugee Council, 28 August 2002 (http://www.idpproject.org/); International Crisis Group (2001a: 2). Many narrative details (but not the environmental connection) in this paper are elaborated in van Klinken (2007).

7 Pengungsi di Madura tolak relokasi, Kompas 28 April 1999.

8 Edi Patebang, Concessionaires responsible for forest destruction, Jakarta Post 4 September 2001; Bupati di Kalimantan Barat masih keluarkan izin $\mathrm{HPHH}$, Kompas 7 November 2003. See also a study on HPHH in Ketapang by Soetarto et al. (2001).

9 Bupati Sintang tahan Rp 37 milyar dana DR/PSDH, Kompas 19 January 2002; Tunggakan dana reboisasi di Kalbar Rp 46,7 miliar, Suara Pembaruan 19 January 2002; Kejahatan lingkungan daerah lemparkan $\mathrm{HPH}$, sembunyikan dana, Sinar Harapan 6 April 2004.

10 Dana tak terbatas untuk tumpas penyelundup kayu di Kalbar, Sinar Harapan 18 June 2003; Sanggau-Sorong merana dilanda illegal logging, Equator 10 July 2003.

11 Empat bupati terlibat kasus penebangan kayu ilegal, Suara Merdeka 24 December 2004.

12 Penyelundupan kayu ilegal ke Malaysia makin parah, Kompas 19 July 2004.
13 Kabupaten konservasi berbasis kesejahteraan, Equator 27 April 2004.

14 Pengusaha rekayasa izin HPH 100 hektar, Kompas 24 February 2001.

15 Central Kalimantan relies for $20 \%$ of its provincial GDP on timber, the highest in Indonesia. West Kalimantan is second but a long way behind, at $8 \%$. Next are Irian Jaya and Maluku at $6 \%$, Jambi at 5\%, and Central Sulawesi and East Kalimantan at $4 \%$. The data, of course, take no account of rampant illegal logging (18 May 1999: Where the (natural resource) wealth is, Jakarta: Embassy of the United States of America, http:// www.usembassyjakarta.org/econ/wealth.html,

accessed 11 January 2005, quoting Indonesian Central Bureau of Statistics data).

16 See the map of West Kalimantan forest cover in 1997, retrieved 27 January 2005 from http://www.dephut. go.id/INFORMASI/INTAG/Peta\%20Tematik/PL_Veg/ veg_97/Vgkalbar.gif.

\section{References}

Alqadrie, S.I. (1990) Ethnicity and social change in Dyaknese society of West Kalimantan, Indonesia. PhD thesis, University of Kentucky.

Ascher, W. (1998) From oil to timber: The political development of off-budget development financing in Indonesia, Indonesia 65: 37-61.

Baechler, G. (1998) Why environmental transformation causes violence: A synthesis, Environmental Change and Security Project Report 4: 24-44.

Bamba, J. (2000) Land, rivers and forests: Dayak solidarity and ecological resilience, in J.B. Alcorn andand A.G. Royo (eds.), Indigenous social movements and ecological resilience: Lessons from the Dayak of Indonesia, pp. 35-60. Washington, DC: Biodiversity Support Program.

Barth, F. (ed.) (1969) Ethnic groups and boundaries: The social organization of cultural difference. London: Allen \& Unwin.

Berger, P. and T. Luckmann (1967) The social construction of reality: A treatise in the sociology of knowledge. Garden City, N.Y.: Doubleday.

Bryant, R. and S. Bailey (1997) Third World political ecology. London: Routledge.

Casson, A. (2001a) Decentralisation of policies affecting forests and estate crops in Kutai Barat District, East Kalimantan. Bogor: CIFOR.

Casson, A. (2001b) Ethnic violence in an era of regional autonomy: A background to the bloodshed in Kotawaringin Timur. Canberra: Australian National University Research School of Pacific and Asian Studies Resource Management in Asia-Pacific Project.

Collier, P. and A. Hoeffler (2004) Greed and grievance in civil war, Oxford Economic Papers 56: 563-595.

Collier, P., V.L. Elliott, H. Hegre, A. Hoeffler, M. ReynalQuerol and N. Sambanis (2003) Breaking the conflict trap: Civil war and development policy. Washington, DC: World Bank and Oxford University Press.

Dauvergne, P. (1997) Weak states and the environment in Indonesia and the Solomon Islands. Canberra: Depart- 
ment of International Relations, Australian National University.

Davidson, J.S. (2002) Violence and politics in West Kalimantan, Indonesia. PhD thesis, University of Washington.

Diehl, P.F. and N.P. Gleditsch (eds.) (2001) Environmental conflict. Boulder, Colorado: Westview Press.

Dove, M. (1982) The myth of the 'communal' longhouse in rural development: The Kantu' of West Kalimantan, in C. MacAndrews and L.S. Chia (eds.), Too rapid rural development: Perceptions and perspectives from Southeast Asia, pp. 14-78. Athens, Ohio: Ohio University Press.

Fearon, J.D. and D.D. Laitin (2003) Ethnicity, insurgency, and civil war, American Political Science Review 97(1): 75-90.

Goldstone, J.A. (2001) Demography, environment, and security, in P.F. Diehl and N.P. Gleditsch (eds.), Environmental conflict, pp. 84-108. Boulder, Colorado: Westview Press.

Goldstone, J.A., T.R. Gurr, B. Harff et al. (2000) State failure task force report: Phase III findings. McLean, Virginia: Science Applications International Corporation (SAIC). Retrieved 16 June 2006, from Website: http:// globalpolicy.gmu.edu/pitf/ SFTF\%20Phase\%20III\%20Report\%20Final.pdf

Gurr, T.R. (1970) Why men rebel. Princeton, New Jersey: Princeton University Press.

Harley (2003) Di balik penghancuran eboni: perlawanan rakyat terhadap ekspansi kapitalis di Sulawesi Tengah. Palu: Walhi.

Harriss-White, B. (2003) India working: Essays on society and economy. Cambridge: Cambridge University Press.

Hauge, W. and T. Ellingsen (2001) Causal pathways to conflict, in P.F. Diehl and N.P. Gleditsch (eds.), Environmental conflict, pp. 36-57. Boulder, Colorado: Westview Press.

Herbst, J. (2000) Economic incentives, natural resources and conflict in Africa, Journal of African Economies 9(3): 270-294.

Homer-Dixon, T.F. (1999) Environment, scarcity, and violence. Princeton, New Jersey: Princeton University Press.

Horowitz, D.L. (1985) Ethnic groups in conflict. Berkeley, California: University of California Press.

Human Rights Watch (1997) Communal violence in West Kalimantan. Washington/New York: Human Rights Watch.

International Crisis Group (2001a) Communal violence in Indonesia: Lessons from Kalimantan. Jakarta/Brussels: ICG.

International Crisis Group (2001b) Indonesia: Natural resources and law enforcement, Asia Report No. 29. Jakarta/Brussels: ICG.

Karl, T.L. (1997) The paradox of plenty: Oil booms and petro-states. Berkeley, California: University of California Press.

King, V.T. (1993) The peoples of Borneo. Oxford: Blackwell.

Klare, M.T. (2001) Resource wars: The new landscape of global conflict. New York: Metropolitan Books.

van Klinken, G. (2002) Indonesia's new ethnic elites, in $\mathrm{H}$. Schulte Nordholt and I. Abdullah (eds.), Indonesia: In search of transition, pp. 67-105. Yogyakarta: Pustaka Pelajar.

van Klinken, G. (2007) Communal violence and democratization in Indonesia: Small town wars. London: Routledge.

Le Billon, P. (2001) The political ecology of war: Natural resources and armed conflicts, Political Geography 20: $561-584$.

Linder, D. (1997) Ethnic conflict and deforestation in Kalimantan (Indonesia). Inventory of Conflict and Environment (ICE), American University. Retrieved 5 June 2007, from Website: http://www.american.edu/ projects/mandala/TED/ice/KALIMAN.HTM\#r1

Lowenhaupt Tsing, A. (1993) In the realm of the Diamond Queen: Marginality in an out-of-the-way place. Princeton, New Jersey: Princeton University Press.

McAdam, D., S. Tarrow and C. Tilly (2001) Dynamics of contention. Cambridge, New York: Cambridge University Press.

McCarthy, J.F. (2006) The fourth circle: A political ecology of Sumatra's rainforest frontier. Stanford, California: Stanford University Press.

McCarthy, J.F. (2007) Sold down the river: Renegotiating predatory regimes in Central Kalimantan, in $\mathrm{H}$. Schulte Nordholt and G. van Klinken (eds.), Renegotiating boundaries: Local politics in Post-Suharto Indonesia, pp. 151-176. Leiden: KITLV.

Malley, M. (1999) Regions: Centralization and resistance, in D.K. Emmerson (ed.), Indonesia beyond Suharto: Polity, economy, society, transition, pp. 71-105. New York: M. E. Sharpe.

Manning, C. and P. van Diermen (eds.) (2000) Indonesia in transition: Social aspects of reformasi and crisis. Singapore: Institute of Southeast Asian Studies.

Padoch, C. and N.L. Peluso (eds.) (1996) Borneo in transition: People, forests, conservation and development. Kuala Lumpur: Oxford University Press.

Peluso, N.L. (2003) Weapons of the wild: Strategic uses of violence and wildness in the rain forests of Indonesian Borneo, in C. Slater (ed.), In search of the rain forest, pp. 204-245. Durham, North Carolina: Duke University Press.

Peluso, N.L. and E. Harwell (2001) Territory, custom, and the cultural politics of ethnic war in West Kalimantan, Indonesia, in N.L. Peluso and M. Watts (eds.), Violent environments, pp. 83-116. Ithaca, New York: Cornell University Press.

Peluso, N.L. and M. Watts (eds.) (2001) Violent environments. Ithaca, New York: Cornell University Press.

Renner, M. (2002) The anatomy of resource wars. Washington, DC: Worldwatch Institute.

Reno, W. (1995) Corruption and state politics in Sierra Leone. Cambridge: Cambridge University Press.

Ross, M.L. (1999) The political economy of the resource curse, World Politics 51(2): 297-322.

Ross, M.L. (2001) Timber booms and institutional breakdown in Southeast Asia. Cambridge: Cambridge University Press.

Rød, J.K. and S.A. Rustad (2006) Forest resources and conflict: Conflict zones and disaggregated forest data. Paper prepared for the workshop Polarization and Conflict, Nicosia, Cyprus, 26-29 April. Retrieved 27 
May 2007, from Website: http://www.prio.no/files/ file47684_rod_rustad_nicosia_paper.pdf

Soetarto, E., M.T.F. Sitorus and Y. Napiri (2001) Decentralisation of administration, policy making and forest management in Ketapang District, West Kalimantan. Bogor: Centre for International Forestry Research.

de Soysa, I. (2002) Ecoviolence: Shrinking pie or honeypot? Global, Environmental Politics 2(4): 1-34.

de Soysa, I. and E. Neumayer (2003) Natural resources and civil war: Another look with new data. Oslo: Centre for the Study of Civil War (CSCW), International Peace Research Institute (PRIO).

Steinmetz, G. (ed.) (1999) State, culture: State-formation after the cultural turn. Ithaca, New York: Cornell University Press.
Theisen, M. (2006) Other pathways to conflict? Environmental scarcities and domestic conflict. Paper presented to the 47th Annual Convention of the International Studies Association, San Diego, 22 March. Retrieved 5 June 2007, from Website: http://www.isanet.org/ archive.html

Tilly, C. (1978) From mobilization to revolution. New York: Random House.

Varshney, A., R. Panggabean and M.Z. Tadjoeddin (2004) Patterns of collective violence in Indonesia (19902003). UNSFIR Working Paper - 04/03. Jakarta: UNSFIR. Retrieved 16 June 2006, from Website: http://www.unsfir.or.id/files/workingpapers/ 20040902101151.pdf 